Historia Slavorum Occidentis

2021, nr 3 (30)

ISSN 2084-1213

DOI: $10.15804 /$ hso210306

\author{
Zbigniew DaLeWsim (WARSZAWA) \\ ORCID: 0000-0001-9382-8146
}

\title{
Ideologia i symbolika władzy monarszej w badaniach Aleksandra Gieysztora i Gerarda Labudy
}

Słowa kluczowe: Aleksander Gieysztor (1916-1999), Gerard Labuda (1916-2010), historiografia, ideologia władzy, symbolika władzy

Keywords: Aleksander Gieysztor (1916-1999), Gerard Labuda (1916-2010), historiography, ideology of power, symbolism of power

Abstract: This paper discusses Aleksander Gieysztor's and Gerard Labuda's research on the problem of ideology and symbolism of power and presents the main directions of their studies in this field.

Wśród poruszanych w tekstach Aleksandra Gieysztora i Gerarda Labudy tematów, wątków czy zagadnień nie zabrakło też, rzecz jasna, kwestii odnoszących się do problematyki ideologii i symboliki władzy monarszej. Określenie miejsca, jakie przypadało im w ich twórczości, i znaczenia, jakie przywiązywali oni do prowadzonych w tym zakresie studiów, nie jest jednak zadaniem łatwym. Rozmach rozwijanych przez nich badań i ich ogromne tematyczne zróżnicowanie sprawiają, że trudno wskazać obszary badawcze, których - w większym bądź mniejszym stopniu - nie dotykałyby ich prace i na których nie zaznaczyliby oni swojej obecności. W rezultacie powoduje to z jednej strony, że pewne nurty ich studiów mogą wydawać się w porównaniu z innymi słabiej reprezentowane i mniej istotne, i w efekcie mogą one zostać niedocenione. Z drugiej natomiast, skupienie uwagi na wybranej jedynie części dorobku obu uczonych może prowadzić do wyolbrzymienia roli, jaką odgrywała ona w ich badaniach. Nie podejmując zatem próby umiejscowienia prowadzonych przez obu uczonych studiów nad 
zagadnieniami ideologii i symboliki władzy w szerszym kontekście ich wielorakich zainteresowań badawczych i proponowanych przez nich sposobów uprawiania historii, ograniczymy się w tym miejscu do przedstawienia czy też może raczej przypomnienia kilku kwestii, które z różnym natężeniem przewijały się w ich twórczości.

Zagadnienia łączące się z problematyką ideologii i symboliki władzy znalazły się w polu badawczej obserwacji zarówno A. Gieysztora, jak i G. Labudy już w początkowym okresie ich naukowej działalności. W przypadku Gieysztora zagadnień tych dotyczyła jego pierwsza wydana w 1938 r. dłuższa rozprawa naukowa powstała jako praca magisterska na seminarium Marcelego Handelsmana. Zgodnie z zapowiedzianą w jej tytule tematyką - Wtadza Karola Wielkiego w opinii wspótczesnych - podjął się w niej zadania przyjrzenia się funkcjonującym na przełomie VIII i IX w. wyobrażeniom o naturze sprawowanej przez frankijskiego władcę monarszej zwierzchności. Przeprowadzona w niej analiza źródeł zarówno pochodzenia rzymskiego, jak i frankijskiego doprowadziła go do wniosku, że podstawy ideowe władzy Karola określało rozwijane jeszcze przed cesarską koronacją, podzielane zarówno w Rzymie, jak i na frankijskim dworze, przekonanie o jego szczególnej, opartej na boskim nadaniu, odpowiedzialności za całą wspólnotę chrześcijańską i wynikającym stąd obowiązku troski o rozszerzanie jej granic i opieki nad Kościołem ${ }^{1}$.

G. Labuda natomiast poświęcił sporo uwagi kwestiom ideologii i symboliki władzy w wydanych już po wojnie, w 1946 r., ale powstałych jeszcze w okresie jej trwania Studiach nad początkami państwa polskiego. Z pewnością nie znajdowały się one w centrum prowadzonych przez niego w tym dziele rozważań. Zasadniczym celem, jaki stawiał w nim przed sobą autor, była krytyczna weryfikacja podtrzymywanych przez niemieckich badaczy koncepcji o zależności monarchii piastowskiej od Niemiec na najwcześniejszym etapie jej dziejów. Niemniej włączenie do rozwijanego przez niego wykładu wydarzeń związanych ze zjazdem gnieźnieńskim siłą rzeczy prowadziło do uwzględnienia w nim także szerokiego kompleksu zagadnień wiążących się z propagowaną przez Ottona III ideą odnowienia cesarstwa rzymskiego i znaczeniem towarzyszących gnieźnieńskiemu spotkaniu gestów i ceremonialnych zachowań. Dowodząc wiarygodności zawartego w kronice Galla opisu zjazdu gnieźnieńskiego, przynajmniej w odniesieniu do zrelacjonowanego w nim ceremoniału nałożenia polskiemu władcy na głowę korony i przekazania mu włóczni św. Maurycego, Labuda poddał przywołane przez kronikarza zrytualizowane gesty drobiazgowej analizie, próbując wydobyć stojące za nimi treści polityczne i ideowe. Porówna-

1 A. Gieysztor, Wtadza Karola Wielkiego w opinii wspótczesnych, Warszawa 1938. 
nie opisanego przez Galla przebiegu zjazdu gnieźnieńskiego do ceremoniału nadania przez cesarza tytułu patrycjusza pozwoliło mu na odrzucenie cieszących się sporą popularnością w literaturze, zarówno polskiej, jak i niemieckiej, koncepcji o wyniesieniu do tej godności w Gnieźnie również Bolesława Chrobrego. Nie skłoniło go to jednak do uznania tezy o przeprowadzeniu podczas zjazdu królewskiej koronacji polskiego władcy. Prowadzone przez niego rozważania nad rytem królewskiej sakry, obowiązującą na przełomie X i XI wieku procedurą wynoszenia nowych władców do królewskiej godności czy wreszcie przyznawanymi królom uprawnieniami w zakresie władzy nad Kościołem doprowadziły go do wniosku, że w składających się na spotkanie w Gnieźnie aktach ceremonialnych znalazła swój wyraz zgoda cesarza na przyszłą koronację Bolesława - która ze względu na zadzierzgnięte jeszcze przez Mieszka I więzy ze Stolicą Apostolską musiała zostać potwierdzona przez papieża - łącząca się z uznaniem go za suwerennego władcę i przyznaniem mu królewskich praw do zwierzchności nad Kościołem polskim².

Okazywane przez obu uczonych wich pierwszych pracach zainteresowanie problematyką ideologii i symboliki władzy i manifestowane przez nich przekonanie o znaczeniu, jakie dla właściwego rozpoznania rzeczywistości społecznej i politycznej średniowiecza mają badania nad nią towarzyszyło im - w różnym stopniu - także na dalszych etapach ich naukowej działalności. Obaj też - chociaż w innym zakresie - odwoływali się do niej w późniejszych studiach i podejmowali związane z nią tematy.

W przypadku G. Labudy prowadzone w tym kierunku badania w znaczącej mierze stanowily rozwinięcie poruszonych przez niego już w Studiach nad początkami państwa polskiego ściśle powiązanych ze sobą wątków, odnoszących się do kompleksu zagadnień łączących się z postanowieniami zjazdu gnieźnieńskiego, charakterem władzy królewskiej oraz ideą suwerenności i politycznej niezależności.

Pytanie o sens rozstrzygnięć zapadłych na zjeździe gnieźnieńskim powracało $\mathrm{w}$ polskiej mediewistyce z różną intensywnością przez cały niemal okres powojenny. W sposób szczególny jednakże ponowny wzrost zainteresowania tą tematyką zaznaczył się w ostatnich latach XX w. i początkach bieżącego stulecia, najpierw w związku pracą Johannesa Frieda, odrzucającą większość funkcjonujących w historiografii polskiej ustaleń dotyczących zjazdu ${ }^{3}$, a następnie z okazji obchodów rocznicowych ${ }^{4}$.

2 G. Labuda, Studia nad początkami państwa polskiego, Poznań 1946, s. 237-319.

3 J. Fried, Otto III. und Boleslaw Chrobry. Das Widmungsbild des Aachener Evangeliars, der "Akt von Gnesen" und das frühe polnische und ungarische Königtum, Stuttgart 1989.

4 Zob. np. J. Strzelczyk, Naukowe pokłosie millenium zjazdu gnieźnieńskiego, Roczn. Hist. 68 (2002), s. 157-174. 
W toczone wówczas dyskusje aktywnie włączył się także G. Labuda. Wydaje się, że jego uwagę zaprzątały przede wszystkim sprawy związane z kościelną stroną rozgrywających się w Gnieźnie wydarzeń. W każdym razie, publikując w 1988 r. drugi tom Studiów nad początkami państwa polskiego i poruszając ponownie tematykę zjazdu, skupił się głównie na kwestiach związanych z utworzeniem arcybiskupstwa gnieźnieńskiego. W odniesieniu do towarzyszących spotkaniu Bolesława Chrobrego z Ottonem III aktów symbolicznych, w których znalazły uzewnętrznienie postanowienia dotyczące sfery politycznej, powtórzył w zasadzie, w niewielkim stopniu jedynie je modyfikując, swoje wcześniejsze ustalenia. W jego ujęciu ryt nałożenia Bolesławowi na głowę przez Ottona cesarskiej korony służyć miał „wprowadzeniu” polskiego władcy w królewskie prawa, rozumiane przez niego wyłącznie w kategoriach mających przysługiwać piastowskiemu władcy, królewskich w swej istocie uprawnień w zakresie udzielania polskim biskupom inwestytury ${ }^{5}$. Pojawienie się rok później wspomnianej już książki Frieda, w której na nowo wysunięto tezę o przeprowadzeniu w Gnieźnie przez Ottona królewskiej koronacji Bolesława, nie skłoniło G. Labudy do zmiany poglądów w tej sprawie, lecz przeciwnie, zachęciło do podjęcia $\mathrm{z}$ nią polemiki i zajęcia się ponownie gnieźnieńską ceremonią ${ }^{6}$ W publikowanych na przełomie wieków licznych pracach zdecydowanie bronił swojego stanowiska, dowodząc, że w akcie nałożenia Bolesławowi korony w Gnieźnie nie można w żadnym razie widzieć uroczystości królewskiego wyniesienia, która wymagała sankcji papieskiej i dopełnienia w ramach liturgicznej ceremonii sakry ${ }^{7}$.

Prowadzone przez G. Labudę badania nad problematyką kształtowania się instytucji królestwa, charakteru królewskiej władzy i przysługujących koronowanemu monarsze uprawnień, rozwijane niejako przy okazji studiów nad zjazdem gnieźnieńskim, znalazły również pełniejsze przedstawienie w osobnych rozprawach poświęconych specjalnie tej tematyce. Początkowo, w pracach publikowanych we wczesnych latach sześćdziesiątych, skupiał on swoją uwagę przede wszystkim na zagadnieniach związanych z procesem powstawania władzy królewskiej i rozpowszechniania się tytułu króla na obszarze Słowiańszczyzny we wcześniejszym średniowieczu ${ }^{8}$. Zjawisko

5 G. Labuda, Studia nad początkami państwa polskiego, t. 2, Poznań 1988, s. 426-526.

6 Tenże, Zjazd gnieźnieński roku 1000 w oświetleniu ikonograficznym, Kwart. Hist. 98 (1991), s. 3-18.

7 Zob. np. tenże, Zjazd i synod gnieźnieński roku 1000, Kwart. Hist. 107 (2002), s. 108-122; tenże, O badaniach nad zjazdem gnieźnieńskim roku 1000. Spostrzeżenia i zastrzeżenia, Roczn. Hist. 68 (2002), s. 107-156.

8 Tenże, Rozpowszechnienie się tytułu „króla” wśród Słowian, [w:] Wieki Średnie. Medium 
to łączył głównie z zachodzącymi w tym czasie wśród ludów słowiańskich zmianami $\mathrm{w}$ formach organizacji politycznej, prowadzącymi do wykształcenia się władzy monarchicznej w ścisłym znaczeniu tego słowa. Widział w nim jednak również ważne świadectwo utrwalania się politycznej niezależności słowiańskich państw, która miała znajdować swoje symboliczne uzewnętrznienie właśnie w sięganiu przez ich władców po kojarzony jednoznacznie z suwerennością tytuł królewski.

Podejmując później, po ponad trzydziestu latach, jeszcze raz zagadnienie znaczeń łączonych z instytucją królestwa i godnością królewską, G. Labuda pokusił się o syntetyczne przedstawienie przeobrażeń, jakim podlegały wyobrażenia o władzy królewskiej w okresie od schyłku antyku po późne średniowiecze. Szczególnie wiele miejsca poświęcił jednak tej formie - jak określił - sakralizowanego królestwa, jaka rozwinęła się w następstwie wydarzeń związanych najpierw z namaszczeniem Pepina Małego, a później cesarską koronacją Karola Wielkiego. Starał się pokazać, że z ukształtowanym w czasach karolińskich modelem królewskiej władzy, związanej już z liturgiczną ceremonią sakry, zaczęto też stopniowo łączyć w $\mathrm{X}$ w. idee niepodzielności królestwa przekazywanego tylko jednemu z sukcesorów i przypisywać wyróżnionym królewską koroną władcom wyłączne prawo do sprawowania zwierzchności nad Kościołem. $\mathrm{W}$ rezultacie też dla wchodzących u schyłku pierwszego tysiąclecia w ramy porządku religijnego i politycznego łacińskiego Zachodu nowych organizmów państwowych, powstających na peryferiach pokarolińskiego świata, królewska korona zaczęła pełnić funkcję symbolu państwowej suwerenności9 ${ }^{9}$

Rozważania nad pojęciem suwerenności państwowej i jej symbolami obecne są w pracach G. Labudy niemal przez cały okres jego twórczości naukowej. Wyznaczały one główną płaszczyznę, na której rozwijały się jego dociekania dotyczące relacji monarchii piastowskiej z Rzeszą, stanowiące z pewnością jeden z ważniejszych nurtów jego badań ${ }^{10}$. W jego rozumieniu bowiem pojęcie państwa było nierozerwalnie

Aevum. Prace ofiarowane Tadeuszowi Manteufflowi w 60 rocznicę urodzin, Warszawa 1962, s. 57-81; tenże, Wykształcenie władzy królewskiej u Stowian we wczesnym średniowieczu, [w:] Z polskich studiów slawistycznych, ser. 2, Historia. Prace na V Międzynarodowy Kongres Slawistów w Sofii 1963, Warszawa 1963, s. 61-72.

9 Tenże, O godności króla i instytucji królestwa, [w:] Przemyst II. Odnowienie Królestwa Polskiego, red. J. Krzyżaniakowa, Poznań 1997, s. 27-56.

10 Zob. np. tenże, O stosunkach prawnopublicznych między Polska a Niemcami w połowie XII wieku (Merseburg - 1135, Kaina - 1146, Krzyszkowo - 1157), Czasopismo Prawno-Historyczne 25 (1973), s. 25-60; tenże, Stosunki prawno-polityczne Polski i Niemiec w średniowieczu (Program badań), [w:] Niemcy - Polska w średniowieczu. Materiały konferencji naukowej zorganizowanej przez Instytut Historii UAM w dniach 14-16 XI 1983 roku, red. 
związane z suwerennością, w której widział jedną z jego podstawowych cech. Uczony zdecydowanie sprzeciwiał się poglądom odmawiającym wczesnośredniowiecznym organizmom politycznym charakteru państwowego. Przyznawał, co prawda, że we wczesnym i pełnym średniowieczu idea suwerenności miała inną niż współcześnie, swoistą, właściwą epoce formę, określoną przez doktrynę uniwersalizmu cesarskiego i papieskiego. Jednocześnie jednak wskazywał na to, że w praktyce życia politycznego nie niosła ona ze sobą zasadniczych ograniczeń dla koncepcji państwowej niezależności i samodzielności ${ }^{11}$.

W takim ujęciu sprawy włączenie przez Ottona III w Gnieźnie monarchii piastowskiej w struktury uniwersalnego cesarstwa i przyznanie jej w nich takiego samego miejsca, jakie przysługiwało innym chrześcijańskim królestwom, nie tylko nie podważało suwerenności państwa polskiego, lecz przeciwnie - dowodziło jego niezależności i uwalniało je od trybutarnej podległości Niemcom. Niemniej porzucenie po śmierci Ottona przez jego następcę jego koncepcji zmusiło Bolesława Chrobrego do oparcia swoich dążeń do zachowania suwerenności nie na współpracy, lecz na konfrontacji z cesarstwem. Osiągnięciu tego celu służyć miały - jak podkreślał G. Labuda - zabiegi Bolesława o koronację, w której obroniona przez niego w wojnach z Henrykiem II niezależność państwa polskiego mogła znaleźć swoje pełne symboliczne przedstawienie. Nie powinno zatem dziwić, że koronacja Chrobrego wywołała w Niemczech oburzenie, a także że zmuszony do kapitulacji przed Konradem II Mieszko II musiał zrzec się dowodzącej jego suwerenności królewskiej godności. Pamięć o pierwszych piastowskich koronacjach miała też określać, w przekonaniu Labudy, wyobrażenia o naturze władzy polskich władców w XII i XIII wieku, stanowiąc fundament, na którym wspierało się mocno osadzone w tradycji politycznej monarchii piastowskiej przeświadczenie o niezależności Polski wobec cesarstwa. Wokół korony, która pomimo utraty przez władców polskich tytułu królewskiego zachowała rangę symbolu państwowej suwerenności, ogniskować się miały też wspomnienia o minionej świetności i nadzieje na jej odzyskanie.

J. Strzelczyk, Poznań 1986, s. 121-135; tenże, O stosunkach prawno-politycznych państwa polskiego $z$ państwem niemieckim $w X$ X XI wieku. W zwiazku z praca Jarosława Sochackiego pt. Stosunki publicznoprawne między państwem polskim a cesarstwem rzymskim $w$ latach 963-1102, Czasopismo Prawno-Historyczne 57 (2005), s. 327-378.

11 Tenże, Zagadnienie suwerenności Polski wczesnofeudalnej w X-XII wieku, Kwart. Hist. 67 (1960), s. 1035-1068; tenże, Tworzenie się państw narodowych w Europie średniowiecznej, Kwart. Hist. 100 (1993), s. 27-48. 
W odróżnieniu od G. Labudy, kontynuującego w dużym stopniu problematykę poruszaną już przez niego w pierwszych pracach, A. Gieysztor do prowadzonych przed wojną badań nad ideologią karolińską już nie powrócił. Nie znalazła też kontynuacji w jego dalszych studiach, stanowiąca przedmiot pisanej przez niego podczas wojny i wydanej w 1948 r. rozprawy doktorskiej, problematyka ideologii krucjatowej ${ }^{12}$. Zaangażowanie $\mathrm{w}$ prace podejmowane $\mathrm{w}$ ramach programu milenijnego sprawiło, że rozwijane przez niego studia zaczęły skupiać się przede wszystkim na kwestiach dotyczących najstarszych dziejów monarchii piastowskiej. Ważne miejsce przypadło w nich szeroko rozumianej historii kultury, a zwłaszcza, jak to sam ujął, „związkom między podstawami społecznymi a treściami ideowymi występującymi we wcześniejszym średniowieczu polskim”, czyli zagadnieniom „przyjętych norm, wartości i sposobów postępowania, mentalności społecznej, przekonań i ideologii grup oraz klas, mentalności wyrażanej w dziełach i zachowaniach się ludzi”" ${ }^{13}$. W jego rozumieniu rozpoznanie tej problematyki miało w istotny sposób dopełnić obraz pierwszych wieków istnienia państwa polskiego, wyłaniający się z prowadzonych już wcześniej badań nad historią gospodarczą i społeczną.

Przywołane stwierdzenia pochodzą z referatu wygłoszonego przez uczonego na IX Powszechnym Zjeździe Historyków w 1963 r. i wydanego drukiem rok później. Wydaje się jednak, że przedstawione w nim przekonanie o znaczeniu, jakie badania nad tak rozumianą historią kultury mają dla właściwego zrozumienia wielorakich procesów i zjawisk zachodzących w rzeczywistości społecznej i politycznej, można w znaczącej mierze odnieść także do wielu innych jego prac, zarówno publikowanych wcześniej, zwłaszcza od połowy lat pięćdziesiątych, jak i w późniejszym okresie. Podejmowały one szeroki wachlarz różnorodnych tematów skupionych głównie, chociaż nie wyłącznie, wokół kwestii odnoszących się do chrystianizacji monarchii piastowskiej, kultu świętych patronów czy kształtowania się poczucia świadomości narodowej. W prowadzonych w tych tekstach rozważaniach nie zabrakło też uwag dotyczących problematyki ideologii władzy. Wynikało to z przekonania autora o szczególnej roli monarchii jako instytucji, w której przenikały się i skupiały różnorakie więzi społeczne i ideowe, budujące wspólnotę poddanej jej władzy spoleczności. W rezultacie też rozpoznanie manifestowanych w znakach i symbolach, demonstrowanych w zrytualizowanych zachowaniach i działaniach czy wyrażanych

12 A. Gieysztor, Ze studiów nad geneza wypraw krzyżowych. Encyklika Sergiusza IV (1009-1012), Warszawa 1948.

13 Tenże, Podstawy społeczne i treści ideowe kultury wcześniejszego średniowiecza polskiego, [w:] Historia kultury średniowiecznej w Polsce, t. 2, Warszawa 1964, s. 10. 
$\mathrm{w}$ formułowanych na dworze programach ideologicznych, postulowanych i urzeczywistnianych przez władzę monarszą wzorów i norm społecznych oraz relacji politycznych, w istotny sposób miało przyczynić się w jego zamyśle do lepszego zrozumienia głębokich przeobrażeń zachodzących w funkcjonowaniu społeczeństwa polskiego w okresie wcześniejszego średniowiecza.

Szczególnie dużo uwagi poświęcił A. Gieysztor kwestii chrystianizacji monarchii piastowskiej. W jego przekonaniu decyzję Mieszka I o przyjęciu chrztu należało oceniać w kontekście procesów modernizacyjnych, związanych z kształtowaniem się podstawowych struktur organizacji państwowej na ziemiach polskich. $\mathrm{W}$ takim ujęciu sprawy przyjęcie chrześcijaństwa miało stanowić dopełnienie podejmowanych już wcześniej przez warstwę panującą działań związanych z budową instytucji zarządu centralnego, opartego na organizacji grodowej i sieci osad służebnych. Rzecz nie sprowadzała się jednak do możliwości skorzystania w następstwie chrztu z rozwiązań, jakie organizacji państwowej oferował Kościół w sferze instytucjonalnej i administracyjnej. Zdaniem Gieysztora bowiem, to „zamierzenia ideologiczne pozostawały na pierwszym planie służąc stopieniu sfery świeckiej i praktycznej z odświętną i religijną w jedną całość" ${ }^{14}$. Jak wyjaśniał w innym miejscu, wprowadzony w następstwie chrztu „nowy system wartości hierarchizował społeczeństwo w aspekcie ideologicznym, nadając zróżnicowaniu i przedziałom społeczno-politycznym znamię prawie sakralne przez przymierze władzy politycznej z kościołem”15.

To dokonujące się wraz z przyjęciem chrześcijaństwa złączenie struktur państwa i Kościoła określiło też charakter wyobrażeń o władzy monarszej, które pierwsi władcy piastowscy i znaczna część elit politycznych nie tylko sobie szybko przyswoili, lecz - co jeszcze ważniejsze - zaczęli realizować w praktyce.

W opisanych przez Thietmara z Merseburga działaniach Bolesława Chrobrego dotyczących kar spadających na winnych łamania postu i cudzołóstwa widział uczony - podobnie zresztą jak w lepiej poświadczonych źródłowo przedsięwzięciach ustawodawczych władców pozostałych monarchii środkowoeuropejskich (Węgier i Czech) - świadectwo przystąpienia przez Piasta do urzeczywistniania idei budo-

\footnotetext{
14 Tamże, s. 22.

15 A. Gieysztor, Przemiany ideologiczne w państwie pierwszych Piastów a wprowadzenie chrześcijaństwa, [w:] Początki państwa polskiego. Księga Tysiąclecia, red. K. Tymieniecki, t. 2: Społeczeństwo i kultura, Poznań 1962, s. 167-168; zob. też tenże, Ideowe wartości kultury polskiej X-XI wieku. Przyjęcie chrześcijaństwa, Kwart. Hist. 67 (1960), s. 923-940, tenże, Les paliers de la pénétration du christianisme en Pologne au Xe et XIe siècles, [w:] Studi in onore di Amintore Fanfani, t. 1, Milano 1962, s. 329-367.
} 
wania chrześcijańskiego królestwa. Idea ta, oparta na wzorach ottońskich i sięgająca do tradycji karolińskiej, nakładała na władcę - powołanego do rządów przez Boga szczególny obowiązek troski o zbawienie poddanej jego zwierzchności wspólnoty ${ }^{16}$.

Zwieńczenie podjętych przez pierwszych Piastów zabiegów o włączenie sprawowanej przez nich władzy w ramy nowego porządku religijnego miały stanowić królewskie koronacje Bolesława Chrobrego i Mieszka II, które sakralizowały ich rządy i pozwalały wyróżnionym królewskim namaszczeniem polskim władcom występować w charakterze prawdziwie chrześcijańskich monarchów, skupiających w sobie wartości najistotniejsze dla właściwego funkcjonowania podległej im społeczności ${ }^{17}$. Tego ukształtowanego w czasach pierwszej monarchii sakralnego modelu rządów nie naruszył nawet jej upadek, a później niepowodzenie królewskich planów Bolesława Śmiałego. Przywołując w tym kontekście formułę książęcej benedykcji z pontyfikału krakowskiego, A. Gieysztor wskazywał na odwoływanie się w XII w. przez pozbawionych już królewskiej korony piastowskich książąt do rytualnych działań, manifestujących sakralną naturę ich władzy i ich szczególną - jak dowodziły słowa wypowiadanych nad nimi błogosławieństw - rolę gwarantów pomyślności swoich poddanych $^{18}$.

W tym nurcie prowadzonych przez A. Gieysztora badań znajdują miejsce także jego rozważania nad przedstawieniami ikonograficznymi umieszczonymi na Drzwiach Gnieźnieńskich. Skupiają się one, co prawda, na kwestii kształtowania się świadomości narodowej, do której powracał zresztą jeszcze parokrotnie w późniejszych studiach. Niemniej dokonana przez niego analiza widniejących na Drzwiach wyobrażeń i odczytanie zawartego w nich przesłania ideowego pozwoliły mu na uchwycenie zasadniczych konturów kształtujących się drugiej połowie XII w. wyobrażeń o władzy książęcej. Gieysztor wskazywał na współwystępowanie na Drzwiach obok siebie z jednej strony elementów monarchicznych, z drugiej zaś akcentujących rolę Kościoła. Pierwsze znalazły uzewnętrznienie w wizerunkach władców na majestacie, a przede wszystkim w przedstawieniach Bolesława Chrobrego, które ukazywały go jako monarchę równego cesarzowi i zawierały czytelne odwołania do przekonania o szczególnej roli władcy i dynastii. Drugie natomiast najpełniej uwidoczniały się w scenie, w której biskup napominał księcia. W ten sposób w przedstawieniach ikonograficznych umieszczonych na Drzwiach znala-

\footnotetext{
16 A. Gieysztor, Przemiany ideologiczne, s. 158-159.

17 Tamże, s. 168.

18 A. Gieysztor, Podstawy społeczne i treści ideowe, s. 37-38.
} 
zły odzwierciedlenie zachodzące w miarę pogłębiania się podziałów dzielnicowych, nasilania emancypacyjnych dążeń Kościoła i umacniania pozycji możnowładztwa zmiany w charakterze relacji łączących władcę z elitami politycznymi monarchii, prowadzące do konieczności zdefiniowania na nowo podstaw ideowych książęcej władzy i mocniejszego niż wcześniej zaznaczenia udziału możnych w sprawowanych przez księcia rządach ${ }^{19}$.

W rozważaniach nad programem ideologicznym Drzwi Gnieźnieńskich A. Gieysztor wiele uwagi poświęcił, co oczywiste, postaci św. Wojciecha i rozwijanemu wokół niego kultowi. W sposób szczególny zajmowała go kwestia roli świętego jako patrona monarchii piastowskiej, skupiającego w sobie wartości składające się na żywione przez jej mieszkańców poczucie wspólnoty. Do kwestii związanych z ideowymi treściami łączonymi z kultem przede wszystkim św. Wojciecha, ale także innych świętych, uczony powracał zresztą jeszcze niejednokrotnie. W prowadzonych w tym zakresie badaniach wskazywał na to, że w okresie pierwszej monarchii, ale także później, mamy do czynienia z w pełni świadomą recepcją niosących ważne ideowe i polityczne treści kultów, wykorzystywanych przez władców piastowskich do budowania własnego wizerunku monarszego i umacniania swojej pozycji zarówno w relacjach z innymi władcami chrześcijańskimi, jak i w odniesieniu do elit politycznych w kraju. Przepajające propagowane przez władców piastowskich koncepcje władzy monarszej i rozwijane przez nich programy ideologiczne przeświadczenie nie tylko o daleko posuniętym sprzężeniu instytucji państwa i Kościoła, lecz także wręcz o tożsamości struktur państwowych i kościelnych znalazło swoje zwieńczenie w działaniach Bolesława Chrobrego prowadzących do wykreowania własnych świętych, w pierwszej kolejności rzecz jasna św. Wojciecha, ale również Pięciu Braci czy św. Brunona z Kwerfurtu ${ }^{20}$.

Osobne, wyróżnione miejsce w twórczości A. Gieysztora zajmują studia nad ceremoniałem, symboliką i insygniami władzy, skupione - ze względu na charakter materiału źródłowego - w odróżnieniu od większości jego pozostałych prac na

19 Tenże, Problematyka ideologiczna drzwi gnieźnieńskich, Kwart. Hist. 62 (1955), s. 142-161; tenże, Drzwi Gnieźnieńskie jako wyraz polskiej świadomości narodowościowej w XII wieku, [w:] Drzwi Gnieźnieńskie, red. M. Walicki, t. 1, Wrocław 1956, s. 1-19.

20 Tenże, Sanctus et gloriosissimus martyr Christi Adalbertus: un état et une église missionaires aux alentours de l'an mille, [w: Settimane di studio del Centro italiano di studi sull'alto medioevo, t. 14: La conversione al cristianesino nell'Europa dell'alto medioevo, Spoleto 1967-1967, s. 611-647; zob. też tenże, Politische Heiligen im hochmittelalterlichen Polen und Böhmen, [w: ] Politik und Heiligenverehrung im Hochmittelalter, hrsg. v. J. Petersohn, (Vorträge und Forschungen, 42), Sigmaringen 1994, s. 325-341. 
późnym średniowieczu i wychodzące nawet w czasy nowożytne. Zainteresowanie tą problematyką, wynikające z podzielanego przez niego przekonania o jej znaczeniu dla pełniejszego zrozumienia ideowych uwarunkowań sprawowania władzy i możliwościach, jakie oferuje podjęcie badań w tym zakresie, w różnym stopniu przebijają już z wielu jego wcześniejszych prac. W pełni jednak zajął się tymi zagadnieniami dopiero pod koniec lat sześćdziesiątych. W 1969 r. ukazał się jego artykuł poświęcony problematyce korony zamkniętej, w którym podjął kwestię relacji między wprowadzaniem do praktyki ceremonialnej władców polskich na przełomie średniowiecza i epoki nowożytnej tego właśnie typu insygnialnego nakrycia głowy a upowszechnianiem się przeświadczenia o suwerennym charakterze władzy polskich królów ${ }^{21}$.

W kolejnej pracy odnoszącej się do tej tematyki zajął się natomiast uroczystościami koronacyjnymi polskich królów, podkreślając, że liturgiczna ceremonia sakry wyznaczała tylko jedną z płaszczyzn rozwijania rytu królewskiego wyniesienia i przenikała się, znajdując w nich dopełnienie, ze spektaklami o świeckim czy nawet ludycznym charakterze, osadzającymi obrzęd stanowienia nowego władcy w szerokim kompleksie wyobrażeń, o odległej niekiedy metryce, dotyczących społecznych oczekiwań łączonych z królewską godnością ${ }^{22}$. W następnych latach, niemal do ostatnich chwil swojej naukowej aktywności, podejmował te zagadnienia jeszcze parokrotnie, zarówno w ujęciach ogólniejszych, pisząc o monarszej ostentacji czy symbolach suwerennej władzy, jak i w bardziej szczególowych, analitycznych studiach dotyczących królewskich gestów czy koronacji Henryka Walezego ${ }^{23}$.

21 Tenże, „Non habemus caeseram nisi regem”. Korona zamknięta królów polskich w końcu XV wieku i w wieku XVI, [w:] Muzeum i twórca. Studia z historii sztuki i kultury ku czci prof. dr Stanisława Lorentza, Warszawa 1969, s. 277-292, wersja francuska, tenże, „Non habemus caeseram nisi regem". La couronne fermée des rois de Pologne à la fin de XVe et au XVIe siècle, Bibliothèque de l'école des chartres 127 (1969), s. 5-26.

22 Tenże, Spektakl i liturgia - polska ceremonia królewska, [w:] Kultura religijna a kultura masowa późnego średniowiecza, red. B. Geremek, Wrocław 1978, s. 9-23.

23 Tenże, „Ornamenta regia” w Polsce XV wieku, [w: ] Sztuka i ideologia XV wieku, red. P. Skubiszewski, Warszawa 1978, s. 155-163; tenże, Gestures in the Coronation Ceremonies of Medieval Poland, [w:] Coronations: Medieval and Early Modern Monarchic Ritual, ed. J.M. Bak, Berkeley-Los Angeles-Oxford 1990, s. 152-164; tenże, Le ceremonial du couronnement des rois de Pologne: le sacre d'Henri de Valois en 1574, [w:] Le sace des rois. Actes du Colloque international d'histoire sur les sacres et couronnements royaux (Reims 1975), Paris 1985, 119-127; tenże, Royal Emblems and the Idea of Sovereignty in Late Medieval and Early Modern Poland, [w: ] State and Society in Europe from the Fifteenth to the Eighteenth Century, ed. J. Pelensky, Warsaw 1985, s. 55-74. 
Rozpoczynając studia nad monarszymi rytuałami, A. Gieysztor wkraczał na obszar, który w polskich badaniach mediewistycznych nie cieszył się dużą popularnością. Rozważania nad polskim ceremoniałem koronacyjnym i insygniami władzy były podejmowane przez polskich historyków, głównie zresztą historyków prawa - należy tu przywołać przede wszystkim nazwiska Stanisława Kutrzeby i Oswalda Balzera $^{24}$ - w nieco większym stopniu jedynie w początkach XX w. W późniejszym okresie, zarówno w latach międzywojennych, jak i po wojnie, pozostawały one zasadniczo poza głównym nurtem prowadzonych w polskiej mediewistyce badań. Rozwijające się bujnie, już od lat dwudziestych XX w., zarówno w Niemczech, jak i we Francji czy w historiografii anglosaskiej studia nad ceremoniałem i insygniami monarszymi nie spotykały się w Polsce z większym odzewem.

Podjęte przez A. Gieysztora studia nad królewskimi rytuałami i symbolami nie sprowadzały się jednak do odniesienia do materiału polskiego kwestionariusza pytań i metod badawczych stosowanych w dominujących wówczas w mediewistyce badaniach nad znakami władzy, wiązanymi przede wszystkim z nazwiskiem Percy'ego Ernsta Schramma ${ }^{25}$. W nie mniejszym stopniu inspiracje dla własnych poszukiwań na tym polu czerpał on z dorobku semiotyki i antropologii kulturowej. Taki sposób podejścia pozwolił mu na znaczne rozszerzenie pola obserwacji i spojrzenie na królewskie rytuały i symbole przez pryzmat składającego się na nie złożonego systemu gestów i znaków, w których uzewnętrzniała się stojąca za nim struktura społeczna. W rezultacie też odczytanie zawartego w rytuale komunikatu miało prowadzić, w jego przekonaniu, do uchwycenia zasadniczych konturów świata wyobrażeń, określających charakter wartości konstytuujących grupę społeczną i decydujących o naturze relacji łączących jej członków.

Przedstawiony skrótowy przegląd prowadzonych przez A. Gieysztora i G. Labudę badań nad problematyką ideologii i symboliki władzy z pewnością nie wyczerpuje wszystkich wątków i tematów poruszanych przez nich w podejmowanych w tym zakresie studiach. Nie miał on zresztą takiego celu. Nie stawiał również przed sobą zadania krytycznej oceny ich dokonań na tym polu. Przypomnienie dorobku obu

24 Zob. np. Ordo coronandi regis Poloniae, wyd. S. Kutrzeba, Archiwum Komisji Historycznej 9 (1909-1913) , s. 133-216; S. Kutrzeba, Źródła polskiego ceremoniału koronacyjnego, Przegl. Hist. 12 (1911), s. 71-83, 149-164, 285-307; O. Balzer, Skarbiec i archiwum koronne w dobie przedjagiellońskiej, Lwów 1917.

25 Zob. np. P.E. Schramm, Herrschaftszeichen und Staatssymbolik. Beiträge zu ihrer Geschichte vom dritten bis zum sechzehnten Jahrhundert, t. 1-3, Stuttgart 1954-1956; tenże, Kaiser, Könige und Päpste. Gesammelte Aufsätze zur Geschichte Mittelalters, t. 1-4, Stuttgart 1967-1971. 
uczonych służyć miało przede wszystkim pokazaniu, jak bardzo ich poglądy, przy wszystkich występujących między nimi różnicach, wpłynęły - zarówno w sensie ich akceptacji, rozwijania i pogłębiania, jak i polemiki z nimi - na funkcjonujące w polskiej mediewistyce sposoby rozumienia zagadnień ideologii władzy i jak bardzo polska mediewistyka, także w odniesieniu do badań nad tymi kwestiami, w dalszym ciągu zależna jest od poczynionych przez nich ustaleń.

Nadesłany: 10 XII 2020

Nadesłany po poprawkach recenzyjnych: 13 VIII 2021

Zaakceptowany: 14 VIII 2021

Prof. dr hab. Zbigniew Dalewski

Instytut Historii im. Tadeusza Manteuffla Polskiej Akademii Nauk

Rynek Starego Miasta 29/31

00-272 Warszawa

e-mail: zbigdal@gmail.com

\section{Résumé}

\section{Ideology and Symbolism of Monarchic Power in the Research of Aleksander Gieysztor and Gerard Labuda}

This paper presents the achievements of Aleksander Gieysztor and Gerard Labuda in the studies of the ideology and symbolism of power. It shows that both scholars investigated these issues from the very beginning of their scholarly work and explored them with varying intensity throughout almost the entire period of their professional activity. It argues that both scholars shared the conviction that research into the ideology and symbolism of power can significantly contribute to a better understanding of the social and political reality of the Middle Ages.

Translated by Agnieszka Tokarczuk

\section{Bibliografia/Bibliography}

Balzer O., Skarbiec i archiwum koronne w dobie przedjagiellońskiej, Lwów 1917 Fried J., Otto III. und Boleslaw Chrobry. Das Widmungsbild des Aachener Evangeliars, der „Akt von Gnesen” und das frühe polnische und ungarische Königtum, Stuttgart 1989 
Gieysztor A., Drzwi Gnieźnieńskie jako wyraz polskiej świadomości narodowościowej w XII wieku, [w:] Drzwi Gnieźnieńskie, red. M. Walicki, t. 1, Wrocław 1956, s. $1-19$

Gieysztor A., Gestures in the Coronation Ceremonies of Medieval Poland, [w:] Coronations: Medieval and Early Modern Monarchic Ritual, ed. J.M. Bak, Berkeley-Los Angeles-Oxford 1990, s. 152-164

Gieysztor A., Ideowe wartości kultury polskiej X-XI wieku. Przyjęcie chrześcijaństwa, Kwartalnik Historyczny 67 (1960), s. 922-940

Gieysztor A., Le ceremonial du couronnement des rois de Pologne: le sacre d'Henri de Valois en 1574, [w:] Le sace des rois. Actes du Colloque international d'histoire sur les sacres et couronnements royaux (Reims 1975), Paris 1985, s. 119-127

Gieysztor A., Les paliers de la pénétration du christianisme en Pologne au Xe et XIe siècles, [w: ] Studi in onore di Amintore Fanfani, t. 1, Milano 1962, s. 329-367

Gieysztor A., „Non habemus caeseram nisi regem”. Korona zamknięta królów polskich w końcu XV wieku i w wieku XVI, [w: ] Muzeum i twórca. Studia z historii sztuki i kultury ku czci prof. dr Stanistawa Lorentza, Warszawa 1969, s. 277-292

Gieysztor A., „Non habemus caeseram nisi regem”. La couronne fermée des rois de Pologne à la fin de XVe et au XVIe siècle, Bibliothèque de l'école des chartres 127 (1969), s. 5-26

Gieysztor A., „Ornamenta regia” w Polsce XV wieku, [w: ] Sztuka i ideologia XV wieku, red. P. Skubiszewski, Warszawa 1978, s. 155-163

Gieysztor A., Podstawy społeczne i treści ideowe kultury wcześniejszego średniowiecza polskiego, [w:] Historia kultury średniowiecznej w Polsce, t. 2, Warszawa 1964, s. $7-40$

Gieysztor A., Politische Heiligen im hochmittelalterlichen Polen und Böhmen, [w: ] Politik und Heiligenverehrung im Hochmittelalter, hrsg. v. J. Petersohn, (Vorträge und Forschungen, 42), Sigmaringen 1994, s. 325-341

Gieysztor A., Problematyka ideologiczna drzwi gnieźnieńskich, Kwartalnik Historyczny 62 (1955), s. 142-161

Gieysztor A., Przemiany ideologiczne w państwie pierwszych Piastów a wprowadzenie chrześcijaństwa, [w: Początki państwa polskiego. Księga Tysiąclecia, red. K. Tymieniecki, t. 2: Społeczeństwo i kultura, Poznań 1962, s. 155-170

Gieysztor A., Royal Emblems and the Idea of Sovereignty in Late Medieval and Early Modern Poland, [w:] State and Society in Europe from the Fifteenth to the Eighteenth Century, ed. J. Pelensky, Warsaw 1985, s. 55-74

Gieysztor A., Sanctus et gloriosissimus martyr Christi Adalbertus: un état et une église 
missionaires aux alentours de l'an mille, [w:] Settimane di studio del Centro italiano di studi sull'alto medioevo, t. 14: La conversione al cristianesino nell'Europa dell'alto medioevo, Spoleto 1967-1967, s. 611-647

Gieysztor A., Spektakl i liturgia - polska ceremonia królewska, [w:] Kultura religijna a kultura masowa późnego średniowiecza, red. B. Geremek, Wrocław 1978, s. 9-23 Gieysztor A., Władza Karola Wielkiego w opinii wspótczesnych, Warszawa 1938 Gieysztor A., Ze studiów nad geneza wypraw krzyżowych. Encyklika Sergiusza IV (1009-1012), Warszawa 1948

Kutrzeba S., Źródła polskiego ceremoniału koronacyjnego, Przegląd Historyczny 12 (1911), s. 71-83, 149-164, 285-307

Labuda G., O badaniach nad zjazdem gnieźnieńskim roku 1000. Spostrzeżenia i zastrzeżenia, Roczniki Historyczne 68 (2002), s. 107-156

Labuda G., O godności króla i instytucji królestwa, [w:] Przemyst II. Odnowienie Królestwa Polskiego, red. J. Krzyżaniakowa, Poznań 1997, s. 27-56

Labuda G., O stosunkach prawno-politycznych państwa polskiego z państwem niemieckim w X i XI wieku. W związku z praca Jarosława Sochackiego pt. Stosunki publicznoprawne między państwem polskim a cesarstwem rzymskim w latach 963-1102, Czasopismo Prawno-Historyczne 57 (2005), s. 327-378

Labuda G., O stosunkach prawnopublicznych między Polska a Niemcami w połowie XII wieku (Merseburg - 1135, Kaina - 1146, Krzyszkowo - 1157), Czasopismo Prawno-Historyczne 25 (1973), s. 25-60

Labuda G., Rozpowszechnienie się tytułu „króla” wśród Stowian, [w:] Wieki Średnie. Medium Aevum. Prace ofiarowane Tadeuszowi Manteufflowi w 60 rocznicę urodzin, Warszawa 1962, s. 57-81

Labuda G., Stosunki prawno-polityczne Polski i Niemiec w średniowieczu (Program badań), [w: ] Niemcy - Polska w średniowieczu. Materiały konferencji naukowej zorganizowanej przez Instytut Historii UAM w dniach 14-16 XI 1983 roku, red. J. Strzelczyk, Poznań 1986, s. 121-135

Labuda G., Studia nad początkami państwa polskiego, Poznań 1946

Labuda G., Studia nad początkami państwa polskiego, t. 2, Poznań 1988

Labuda G., Tworzenie się państw narodowych w Europie średniowiecznej, Kwartalnik Historyczny 100 (1993), s. 27-48

Labuda G., Wykształcenie władzy królewskiej u Stowian we wczesnym średniowieczu, [w: ] Z polskich studiów slawistycznych, ser. 2 Historia. Prace na V Międzynarodowy Kongres Slawistów w Sofii 1963, Warszawa 1963, s. 61-72 
Labuda G., Zagadnienie suwerenności Polski wczesnofeudalnej w X-XII wieku, Kwartalnik Historyczny 67 (1960), s. 1035-1068

Labuda G., Zjazd gnieźnieński roku 1000 w oświetleniu ikonograficznym, Kwartalnik Historyczny 98 (1991), s. 3-18

Labuda G., Zjazd i synod gnieźnieński roku 1000, Kwartalnik Historyczny 107 (2002), s. 108-122

Ordo coronandi regis Poloniae, wyd. S. Kutrzeba, Archiwum Komisji Historycznej 9 (1909-1913) , s. 133-216

Schramm P.E., Herrschaftszeichen und Staatssymbolik. Beiträge zu ihrer Geschichte vom dritten bis zum sechzehnten Jahrhundert, t. 1-3, Stuttgart 1954-1956

Schramm P.E., Kaiser, Könige und Päpste. Gesammelte Aufsätze zur Geschichte Mittelalters, t. 1-4, Stuttgart 1967-1971

Strzelczyk J., Naukowe pokłosie millenium zjazdu gnieźnieńskiego, Roczniki Historyczne 68 (2002), s. 157-174 